resonance extended up to the nipple, and to the left as far as the posterior axillary line. There was no obliteration of liver dull ness. The rectum was not ballooned. A catheter was passed, but only about 2 drachms of urine escaped. Very little urine had been passed since the onset of symptoms. The patient wished to be sick, and I gave her a teacupful of warm water with bicarbonate of soda. Although this was not vomited, the normal stomach area remained entirely tympanitic, but the dalliness in the left flank and left iliac region increased. Havng given $\frac{1}{4}$ grain of morphine hypodermically, I had her removed to hospital for operstion.

At 6 p.m. Mr. John Hartley opened the abdomen. A large swelling like an overian oyst presented in the wound. It was swelng tik ave oyst presented in the wound. It wa tympanitic above but dull below, and was found to fill the whole of the front of the abdomen. It was recognized as an enormously distended stomach, the greater curvature being hidden below the pubis, and the lesser curvature appearing like dilatation dilatation seemed to extend to the second stage of the duodenum. An area of the stomach was drawn forward and packed off with gauze from the peritoneal cavity. A small incision was, made to allow gas to escape. Then the patient was turned on her right side, the stomach kept drawn forward and the incision enlarged. Fluid containing fig juice and emitting a stron vinous odour, flowed freely for a time, and then masses of halfmasticated figs were removed with a scoop. The pylorus and the first part of the duodenum were found to be dilated suffi ciently to admit three fingers. When all the contents had been removed the stomech contrected gredually till the greater curremoved the stomach contracted gradually till tho greater curstomach was closed in three layers, and the abdominal wall stomach was closed in three layers, and the abdo

The patient bore the operation well, had a fair night, and expressed herself as much more comfortable next morning. No expresed horte morning. No sickness followed the anasthetic nor was there any disturbance of digestion during convalescence. She was fed by nutrien enemata for two days and no solid food was given for a week. Recovery was uneventfal and complete.

Looking back on this case, one wonders how the branches of the ragi in the stomach could recover. Some of them must have been stretched to three times their usuel length. Is it not possible that this may account for the attacks of djspnoes?

\section{THE TREATMENT OF APPENDICAL ABSCESS WITH PURE CARBOLIC ACID AND IODOFORM.}

BY A. ERNEST MAYLARD, M.B., B.S., SURGEON TO THE VICTORIA INFIRMARY, GLASGOW.

The value of pure carbolic acid as a preventive of sepsis has been known since 1865, when Lister first employed it for that purpose in compound fractures. How powerful a deterring agent it is to the extension of septic processe is well known to all those who have employed it to check the advance of traumatic gangrene. By freely swabbing a putrid wound and soaking with the acid all necrosing tissue any further extension of the gangrenous process is prevented, and in a very short time pain and lever disappear and the wound takes on a healthy healing action.

The striking inhibitive effects of the drug when thus used for external conditions led me to venture upon its employment for cases of appendical abscess where the extreme offensiveness of the discharge and the necrotic processes in the appendix suggest conditions not altogether anlike those met with in traumatic gangrene.

\section{Operation.}

Let me outline the method of procedure before making further comment:

1. The abdomen is opened in the right iliac region by the usual "gridiron" incision. Should more room be required the incision" must be carried either upwards or downwards, dividing the fibres crossways of the internal oblique and transversalis muscles. This extension of the wound should always be avoided, if possible, as rendering the subsequent formation of a hernial protrusion mach more likely.

2. If there are no adhesions encountered between the visceral and parietal peritoneum sufficient to effectually cut off the general peritoneal cavity, gauze plugs are inserted so as to afford complete protection of the cavity when the abscess is opened.

3. The abscess is now sought for by carefully breaking down the adhesions, and when once pus begins to well up it is rapidly swabbed away until the cavity has been freely exposed and praotically dried.

4. The appendix is then sought for, and, if reasonably possible, removed; the crecal stump is touched with pure carbolic acid, and invaginated by a purse-string gut sutare.

5. The abscess cavity is freely wiped with a small gauze swab soaked in pure carbolic acid. An effort is made to reach every part of the cavity. A dry swab is then introduced to soak up any of the remaining acid, and immediately thereafter any amount up to half a teaspoonfal of iodoform is put into the cavity, and with a blunt instrument smeared over its walls.

6. A rubber drainage tube about a quarter of an inch in diameter is conducted to the lowest part of the cavity, and on one side of the tube a narrow strip of iodoform gauze is packed in zigzag fashion, just sufficient to fill the cavity; this, with the tube, is conducted out of the abdomen about the centre of the wound.

7. The protective ganze plags encircling the involved area are withdrawn, the edges of the wound dusted with iodoform, and closed by through-and-through silkworm gut sutares.

After-Treatment.

The after-treatment is as follows: On the second day atter the operation the iodoform gauze packing is partially removed; on the third day it is completely removed; and, however fetid may have been the pus at the time of operating, the plug will be found to be perfectly "sweet." On the fifth or sixth day the drainage tube is taken away and on the tenth day the stitches are remored. At the end of four weeks the patient is allowed up.

\section{Synopsis of Casers.}

The accompanying table, which I have been enabled to draw up mainly through the kind help of my Resident Infirmary Assistant, Dr. John P. Kinloch, contains all the cases in the hospital in which I have used pure carbolic acid in the way just described.

It will be noticed, first, that in 16 out of the 27 cases the abscess was reached by the ordinary "gridiron" incision, neither muscle nor aponeurosis being divided across the direction of their fibres.

Secondly, in every instance the peritoneal cavity was opened-that is to say, the abscess had to be reached through the non-adherent walls of the visceral and parietal peritoneam.

Thirdly, in 25 cases out of the 27 the appendix was sought for and removed. In one of the remaining two it was only partially removed, as a portion had disappeared, while in the other it could not be found.

Fourthly, every case recovered, and in none were there any subsequent complications, such as subdiaphragmatic abscess, pylephlebitis, pneumonia, or other conditions suggestive of septic absorption or local accumulations. The palse and temperature usually fell within twentyfour hours.

Fifthly, the subsequent results of operation were traced in 25 out of the 27 crses, and 19 of these 25 were seen and examined. With the exception of the twenty-seventh case, which had only been operated upon a month previously, the interval between operation and report ranged from three months to four and three-quarter years. An examination of these results shows: (1) That where the "gridiron" incision was employed in 10 out of 14 cases there was some bulging of the cicatrix, mostly slight and in almost every instance at the place where the drainage tube and gauze packing emerged. (2) That where the internal, obligue, and transversalis muscles were cut across by extending the incision upwards 3 out of 6 cases showed balging, the protrusion baing in one case at the seat of exit of the drainage tabe, and in the other two at the lower part of the cicatrix. (3) That where the internal oblique and transversalis muscles were cut across by extending the incision downwards and inwards the three cases so treated showed bulging-in one "considerable bulging for about 5 in."; in a second " marked bulging at lower part"; and in a third "slight bulging at lower part." Thus, then, it is seen, in reviewing these results collectively, that out of 23 cases only 7 showed no signs of bulging, and lapse of time may even lessen still more the number of these latter. Further, the bulging was least in those cases in which a "gridiron" 
incision was employed with no cross division of muscle or aponeurotic fibres. And, lastly, that while the number of cases is possibly too few to admit of a very positive statement-9 in all-where the incision had to be carried either upwards or downwards, it seems probable that downward extension is more likely to be followed by a bulging cicatrix than upward.

\section{Conclusions.}

1. That, where proper precautions are taken to protect the general peritoneal cavity, this method of operating admits of every abscess being opened and every appendix sought for and removed with perfect safety.

Cases of Uncomplicated Appendical Abscess Treated with Pure Carbolic Acid and Iodoform.

\begin{tabular}{|c|c|c|c|c|c|}
\hline No. & Sex. & Age. & $\begin{array}{c}\text { Nature of Abdominal } \\
\text { Opening. }\end{array}$ & $\begin{array}{l}\text { Date of } \\
\text { Exami- } \\
\text { nation } \\
\text { after } \\
\text { Opera- } \\
\text { tion. }\end{array}$ & $\begin{array}{c}\text { Condition of } \\
\text { Cicatrix : } \\
\text { a. Reply by Letter; } \\
\text { b. Patient Seen and } \\
\text { Examined. }\end{array}$ \\
\hline 1 & F. & 37 & $\begin{array}{l}\text { Gridiron; no cross divi- } \\
\text { sion of muscles }\end{array}$ & Years. & $\begin{array}{l}\text { a. Bulging at site of } \\
\text { drainage tube. }\end{array}$ \\
\hline 2 & M. & 22 & $\begin{array}{l}\text { Incision in median line } \\
\text { over situation of ab- } \\
\text { scess }\end{array}$ & $4 \frac{3}{4}$ & b. Ditto. \\
\hline 3 & F. & 12 & $\begin{array}{l}\text { Gridiron; nocross divi- } \\
\text { sion of muscles }\end{array}$ & $4 \frac{1}{2}$ & b. Ditto. \\
\hline 4 & F. & 34 & $\begin{array}{l}\text { Internal oblique and } \\
\text { transversalis muscles } \\
\text { divided upwards }\end{array}$ & $4 \frac{1}{2}$ & a. No bulging. \\
\hline 5 & м. & .53 & $\begin{array}{l}\text { Gridiron; no cross divi- } \\
\text { sion of muscles }\end{array}$ & $3 \frac{5}{6}$ & b. Ditto. \\
\hline 6 & F. & 12 & Ditto & $3 \frac{3}{4}$ & a. Ditto. \\
\hline 7 & M. & 22 & Ditto & $3 \frac{1}{2}$ & Case not traced. \\
\hline 8 & M. & 17 & $\begin{array}{l}\text { Internal oblique and } \\
\text { transversalis muscles } \\
\text { divided downwards }\end{array}$ & $3 \frac{1}{4}$ & Ditto. \\
\hline 9 & F. & 10 & $\begin{array}{l}\text { Gridiron: no cross divi- } \\
\text { sion of muscles }\end{array}$ & 2 & a. No bulging. \\
\hline 10 & M. & 51 & $\begin{array}{l}\text { Internal oblique and } \\
\text { transversalis muscles } \\
\text { divided upwards }\end{array}$ & 2 & b. Ditto. \\
\hline 11 & M. & 39 & Ditto & 2 & $\begin{array}{l}\text { b. Bulging at lower } \\
\text { part. }\end{array}$ \\
\hline 12 & м. & 21 & $\begin{array}{l}\text { Gridiron; nocross divi- } \\
\text { sion of muscles }\end{array}$ & 2 & $\begin{array}{l}b \text {. Marble-size bulg- } \\
\text { ing at site of drain- } \\
\text { age tube. }\end{array}$ \\
\hline 13 & F. & 5 & $\begin{array}{l}\text { Internal oblique and } \\
\text { transversalis muscles } \\
\text { divided upwards }\end{array}$ & $1 \mathbf{2}$ & $\begin{array}{l}b \text {. Bulging at lower } \\
\text { part. }\end{array}$ \\
\hline 14 & M. & 40 & $\begin{array}{c}\text { Internal oblique and } \\
\text { transversalis muscles } \\
\text { divided downwards }\end{array}$ & $1 \frac{1}{2}$ & $\begin{array}{l}b . \text { Considerable } \\
\text { bulging for about } \\
5 \text { inches. }\end{array}$ \\
\hline 15 & M. & 34 & $\begin{array}{l}\text { Gridiron; no cross divi- } \\
\text { sion of muscles }\end{array}$ & 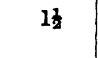 & $\begin{array}{l}\text { b. Bulging at site of } \\
\text { drainage tube. }\end{array}$ \\
\hline 16 & M. & 13 & Ditto & $1 \frac{1}{4}$ & b. Ditto. \\
\hline 17 & м. & 11 & Ditto & $1 \frac{1}{6}$ & b. Ditto. \\
\hline 18 & м. & 21 & $\begin{array}{l}\text { Internal oblique and } \\
\text { transversalis muscles } \\
\text { divided downwards }\end{array}$ & $1 \frac{1}{6}$ & $\begin{array}{l}\text { b. Slight bulging at } \\
\text { lower part. }\end{array}$ \\
\hline 19 & м. & 17 & Ditto & 1 & $\begin{array}{l}\text { b. Bulging marked } \\
\text { at lower part. }\end{array}$ \\
\hline 20 & M. & 8 & $\begin{array}{l}\text { Gridiron; no cross divi- } \\
\text { sion of muscles }\end{array}$ & $\frac{1}{2}$ & a. Slight bulging. \\
\hline 21 & M. & 27 & Ditto & $\frac{1}{2}$ & b. No bulging. \\
\hline 22 & F. & 44 & Ditto & $\frac{1}{2}$ & $\begin{array}{l}\text { b. Bulging at site of } \\
\text { drainage tube. }\end{array}$ \\
\hline 23 & M. & 16 & $\begin{array}{l}\text { Internal oblique and } \\
\text { transversalis muscles } \\
\text { divided upwards }\end{array}$ & $\frac{1}{4}$ & b. Ditto. \\
\hline 24 & M. & 29 & Ditto & $\frac{1}{4}$ & $b$. No bulging. \\
\hline 25 & M. & 22 & $\begin{array}{l}\text { Gridiron; no cross divi- } \\
\text { sion of muscles }\end{array}$ & $\frac{1}{4}$ & $\begin{array}{l}\text { b. Slight bulging at } \\
\text { lower part. }\end{array}$ \\
\hline 26 & F. & 17 & Ditto & $\frac{1}{4}$ & a. Slight bulging. \\
\hline 27 & M. & 56 & Ditto & $\frac{1}{2}$ & $b$. No bulging as yet. \\
\hline
\end{tabular}

NoTE.-The appendix was removed in all cases except No. 4, where removal was partial, and No. 24 where the appendix was not found. The complication in any, and the result in all
2. That this method prevents any subsequent septic complications, such as subdiaphragmatic abscess, pyelephlebitis, pneumonia, thrombosis, and other septic manifestations connected either with the wound locally or with deeper and more distant parts.

3. That, as drainage is considered advisable in every instance, the probabilities are in favour of a weakened cicatrix at the seat of exit of the tube and ganze, with, later, hernial protrusion; but, provided the incision is of the "gridiron" variety, with no cross division of muscle or aponeurotic fibres, and neither the tube too large nor the packing excessive, the bulging may be only slight.

4. That abscess formation in appendicitis must be considered a serious complication, whether regarded in its immediate or in its remote effects; and inasmuch as we can never forecast the possible formation of pus in any given acute attack of appendicitis, we should proceed to remove the appendix before such a complication could take place-that is to say, within, at the latest, forty-eight hours of the initial seizure.

\section{A CASE OF IDIOPATHIC DILATATION OF THE COLON.}

By WILLIAM LEGGETT, M.D.Dub., SENIOR ASSISTANT PHYSICIAN, ROYAL ASYLUM, MONTROSE.

OwING to the comparative rarity of this condition, the following notes and accompanying photographs may be of interest. Unfortunately actual measurements of the patient were not taken in such a way as to be of practical value; but it is possible that the photographs will convey a clearer and more interesting impression of the appearance of the abdomen than a mere statement of measurements.

The patient-an imbecile of low type-a native of Shetland, aged 34 years, first came under notice in May, 1904. No family history was apparently avail. able. He was then described as "suffering from marked disas "suffering from marked diswhose wall the peristaltic movewhose wall the peristaltic movements of the intestines can be readily observed. Over the is a typical syphilitic ulcer, another is situated on the leg posteriorly, at the junction of the middle and lower thirds." Otherwise there appeared to be no marked pathological changes other than the physical defects frequently associated with

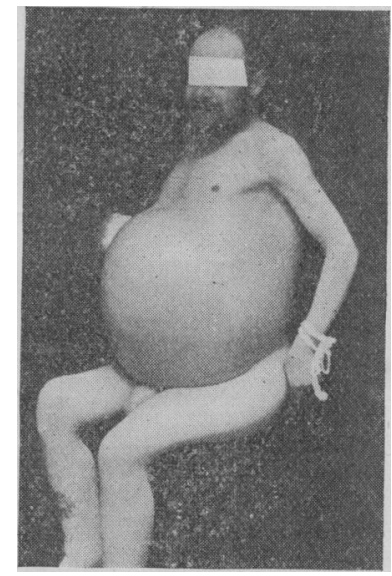
physed with in to distension by giving purgatives and by the administration of enemata, but no appreciable change took place as regards dimensions, though a free action of the bowels resulted from large dose of castor oil. In fact, the abdominal distension appeared to become gradually greater during the first eighteen

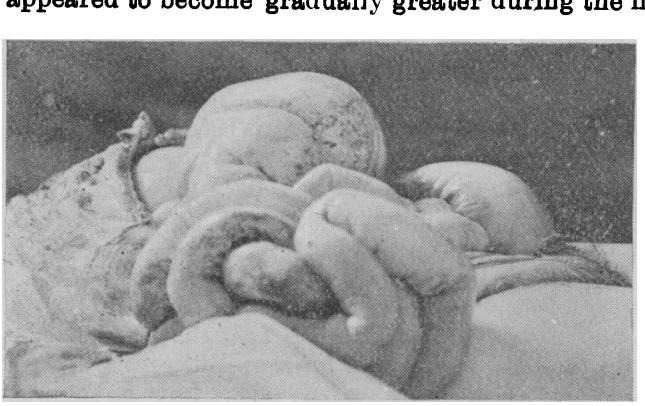
months he was under observation ; then for about two years practically no change took place. At the time-that is, about three and a half years a half years after he seen-he developed, without any apparent cause, a severe attack of diarrhoea, with vomiting and complete disappearance of the distension. After a couple of days, when the diarrhoea had ceased, the abdominal distension returned to about its original size. During all this time the patient persistently refused every kind of medicine, including aperients. Enemata were tried without success. The result was that he sometimes went for ten days or even a fortnight without evacuating the contents of his bowels. These evacut without place withont the administration of anj drage, and the time between successive motions was about seven or eight 